\title{
PENGATURAN TENTANG PENYELESAIAN KONFLIK NORMA ANTARA PERATURAN MENTERI TERHADAP UNDANG-UNDANG
}

\author{
Virginia Usfunan, Program Studi Magister Ilmu Hukum, Fakultas Hukum \\ Universitas Udayana, E-mail: mariavirginia61@yahoo.co.id
}

doi: https://doi.org/10.24843/KS.2020.v08.i08.p07

\begin{abstract}
Abstrak
Tujuan penelitian ini untuk mengetahui bagaimana pengaturan tentang penyelesaian tentang konflik norma antara peraturan menteri terhadap undang-undang dan unruk mengetahui bagaimana sifat putusan mahkamah agung dalam hak uji material. Metode yang digunakan adalah metode penelitian hukum normatif dengan pendekatan perundang-undangan dan pendekatan konsep. Pengaturan tentang penyelesaian konflik norma antara Peraturan Menteri Terhadap Undang-Undang, metode penyelesaian konflik norma itu dengan digunakannya asas lex superior derogate lex inferior ini, yang digunakan dengan terjadinya konflik norma antara UU Peraturan Perundang-Undangan dengan Permenkumham Nomor 2 Tahun 2019 terkait pengaturan penyelesaian konflik norma antara peraturan menteri dengan Undang-Undang, maka berdasarkan asas tersebut yang digunakan adalah UU Peraturan PerundangUndangan, sehingga Permenkumham Nomor 2 Tahun 2019 harus dikesampingkan. Maka, Pengaturan mengenai Penyelesaian Konflik Norma Antara Peraturan Menteri Terhadap Undang-Undang, menjadi kewenangan Mahkamah Agung berdasarkan Pasal 9 UU Peraturan Perundang-Undangan. Dan Sifat Putusan Mahkamah Agung dalam Hak Uji Materiil dalam memberikan putusannya yang pada prinsipnya yang memiliki konsekuensi hukum aturan tersebut apabila terbukti secara sah dan meyakinkan bertentangan dengan aturan di atasnya maka aturan tersebut akan menjadi tidak sah serta tidak berlaku, dan menjadi tanggungjawab instansi terkait untuk mencabutnya.
\end{abstract}

Keywords: Norma Konflik, Mediasi, Hak Uji Material

\begin{abstract}
The purpose of the study is to find how adjustment of the settlement of norm conflicts between Ministerial Regulations toward the Constitution and to find out how the nature of the Supreme Court decision in the right of judicial review. The method used was normative legal research method with the legislation approach and concept approach. Adjustment on resolving norms of conflict between Ministerial Regulations toward the Constitution, the method of resolving norms conflicts by using the principle of lex superior derogate lex inferior, which was used in the norm conflicts between the Constitution on Laws and Regulations with Minister of Law and Human Rights Regulation Number 2 of 2019 in relation to conflict resolution arrangements the norm between Ministerial Regulations and the Constitution, then based on the principle used was the Constitution on Laws and Regulations, so Minister of Law and Human Rights Regulation Number 2 of 2019 must be set aside. Thus, the adjustment on resolving norms of conflict between Ministerial Regulations toward the Constitution became authority of the Supreme Court based on Article 9 of the Constitution on Laws and Regulations. And the nature of the Supreme Court's Decision in the Right to Judge Material in providing its decision which in principle had legal consequences of the rule if it was proven legally and convincingly contrary to the rules above, the rule would be invalid and not applicable, and it was the responsibility of related agencies to revoke it.
\end{abstract}

Keywords: Norm Conflict, Mediation, materiile toetsing 


\section{Pendahuluan}

\subsection{Latar Belakang Masalah}

Indonesia sebagai negara memiliki fungsi sebagai organisasi kekuasaan sebagai penjamin serta memiliki tujuan dalam memajukan, menyejahterakan, mengatur, menertibkan, serta mencerdaskan masyarakat serta bangsa Indonesia. ${ }^{1}$ Indonesia sebagai suatu Negara dalam rangkanya memberikan jaminan dan untuk mencapai tujuan tersebut tentunya dalam menjalankan kekuasaan itu negara membaginya dalam tiga hal yaitu : Kekuasaan Legislatif, Kekuasaan Eksekutif, dan Kekuasaan Yudisial, pembagian kekuasaan ini dicetuskan oleh Montesquieu pada tahun 1689 guna menghindari kekuasaan Negara yang tirani atau semena-mena. ${ }^{2}$

Hukum merupakan instrument yang paling baik digunakan oleh negara guna mengatur masyarakat guna terciptanya tujuan negara tersebut. Hukum dalam hal proses merupakan produk politik yang dibuat oleh DPR RI bersama Presiden. ${ }^{3}$ Maka dari itu, Indonesia seyogyanya menjadikan hukum sebagai hal yang terpenting untuk ditegakkan sebagaimana diatur pada Pasal 1 ayat (3) UUD RI 1945.

Sehingga untuk mewujudkan hal tersebut sebagai amanat daripada Pasal 1 ayat (3) UUD RI 1945, negara mempunyai tanggung jawab menggerakan serta menjalankan pembangunan yang salah satunya merupakan hukum itu tersendiri secara nasional yang secara terpadu, berkelanjutan dan terencana kedalam suatu sistem hukum berskala nasional yang melindungi kewajiban dan hak seluruh masyarakat dalam bingkai konstitusi UUD RI 1945. Pemenuhan kebutuhan atas peraturan yang dapat berdampak positif, sehingga perlu dilakukan pembentukan dan pengundangan suatu peraturan yang mengatur mengenai pembentukan peraturan itu sendiri secara tepat dan baik serta dilakukan dengan teori - teori serta asas - asas hukum yang berhubungan dengan pembentukan peraturan, sehingga standarnya menjadi baik dan hasilnya pun baik. Maka, berdasarkan alasan - alasan tersebut maka diundangakanlah UU Perundang-Undangan.

UU Perundang-undangan mengatur mengenai pembentukan peraturan perundang-undangan sebagai proses pembentukannya dari awal hingga akhir sampai pada pengundanganya, bahkan diatur tentang hal - hal yang berkaitan

${ }^{1}$ Al Hidayat, N., \& Sari, M.. Dualisme Judicial Review Peraturan Perundang-Undangan di Indonesia. Jurnal Magister Hukum Udayana (Udayana Master Law Journal), 7 no 3 (2018), 318328. DOI : https://doi.org/10.24843/JMHU.2018.v07.i03.p04 ·p. 318

2 Syamsudin, M. Tinjauan Politik Islam Terhadap Teori Trias Politica. Al Qisthas: Jurnal Hukum dan Politik Ketatanegaraan, 9 no. 1 (2018), 43-61. URL : http://jurnal.uinbanten.ac.id/index.php/alqisthas/article/view/1413/1164. p. 46

${ }^{3}$ Moh. Mahfud M. D. Politik Hukum di Indonesia. PT. Rajagrafindu Persada. Jakarta Utara (2009). p.4 
dengan kaikutsertaan masyarakat mengenai pembentukan peraturan tersebut. Tidak hanya pada tataran pembentukan, namun diatur juga mengenai pengujian apabila peraturan perundang-undangan yang dibuat, namun diduga terjadi konflik atau pertentangan dengan peraturan di atasnya. Karena pada Pasal 5 UU Perundang-undangan diatur mengenai asas pembentukan peraturan perundang-undangan bahwa harus ada kesesuaian antara jenis dengan hierarkinya. Ini juga didukung dengan adanya Teori Stufenbau yang menyatakan bahwa aturan hukum seperti anak tangga yang harus memperhatikan hierarkinya, norma hukum yang rendah harus berpegangan pada norma hukum yang lebih tinggi, dan hukum yang tertinggi harus berpegangan pada norma hukum yang paling mendasar (grundnorm). ${ }^{4}$ Artinya menurut teori Stefanbau memiliki makna yang pada prinsipnya peraturan perundang-undangan tidak boleh bertentangan dengan peraturan di atasnya. Atas dasar ini lah diatur mengenai pengujian peraturan Perundang-undangan pada Pasal 9 ayat (1) UU Perundang-undangan yang diformulasikan bahwa apabila Undang-Undang bertentangan dengan UUD NRI 1945, maka yang berwenang melakukan pengujian adalah Mahkamah Konstitusi. Sedangkan, pada Pasal 9 ayat (2) mengatur apabila Peraturan Perundang-undangan di bawah Undang-Undang bertentangan dengan Undang-Undang, maka yang memiliki kewenangan untuk dilakukan pengujian adalah Mahkamah Agung. Artinya Pasal ini untuk menjaga kesesuaian antara hierarki daripada Peraturan yang dibuat.

Hukum selalu memiliki celah untuk diperdebatkan dan dipermasalahakan, permasalahan pun terjadi pasca diundangkanya Peraturan Menteri Hukum Dan Hak Asasi Manusia Republik Indonesia Nomor 2 Tahun 2019 Tentang Penyelesaian Disharmoni Peraturan Perundang-Undangan Melalui Mediasi (selanjutnya disebut dalam tulisan ini dengan Permenkumham Nomor 2 tahun 2019) yang dimana salah satu aturanya pada Pasal 2 yang menerangkan bahwa Peraturan Menteri diperiksa dan diselesaikan melalui Mediasi dalam hal terjadi disharmonisasi. Disharmonisasi yang dimaksud adalah dalam hal terjadinya konflik/pertentangan norma hukum sebagaimana penjelasan Permenhukham tersebut dalam Pasal 1 angka 2. Aturan pada Permenkumham Nomor 2 tahun 2019 ini tentu saja bertentangan dengan UU Peraturan Perundang-undangan karena Peraturan Menteri termasuk di dalam hierarki Peraturan Perundang-undangan dibawah Undang-Undang yang seharusnya diuji oleh Mahkamah Agung sebagaimana Pasal 7 dan Pasal 9 UU tersebut, bukan diselesaikan dalam suatu mediasi.

Atas dasar penjabaran mengenai latar belakang masalah yang tersedia, sehingga menjadi sangat relevan menjadi isu terkini dan dijadikan objek dalam

${ }^{4}$ Haryanti, D. Konstruksi Hukum Lembaga Penyelenggara Pemilihan Umum Di Indonesia Ditinjau Dari Teori Stufenbau. Jurnal Pembaharuan Hukum, 2 no 2 (2015), 270-278. DOI: DOI: http://dx.doi.org/10.26532/jph.v2i2.1437. p. 270 
suatu tulisan ilmiah di bidang hukum dengan judul "Pengaturan Penyelesaian Konflik Norma Antara Peraturan Menteri Terhadap Undang-Undang"

Berdasarkan penjabaran diatas dapat dirumuskan 2 (dua) rumusan masalah antara lain Bagaimana Pengaturan Penyelesaian Konflik Norma Antara Peraturan Menteri terhadap Undang-undang ? dan Bagaimana akibat hukum terhadap peraturan menteri pasca pengujian oleh Mahkamah Agung?

Penulisan ini merupakan penulisan ilmiah bidang hukum yang orisinil yang dibuat berdasarkan pemikiran asli dan terbaru. Terdapat pembaharuan hukum ataupun pembahasan pada tulisan ilmiah ini terhadap tulisan-tulisan sebelumnya yang pernah ada dan terpublish pada jurnal-jurnal ilmiah terdahulu. Adapun dapat ditunjukan tulisan ilmiah terdahulu yang mendekati dengan pembahasan pada tulisan ilmiah ini, yaitu :

1. Jurnal ilmiah yang ditulis oleh Nanang Al Hidayat dan Mela Sari, yang keduanya merupakan mahasiswa dari STIA Setih Setio Muara Bungo, jurnal dengan judul "Dualisme Judicial Review Peraturan PerundangUndangan di Indonesia", yang terbit di Jurnal Magister Hukum Udayana, Fakultas Hukum Universitas Udayana, Denpasar, Volume 07, Nomor 03, pada bulan September Tahun 2018.

2. Jurnal ilmiah yang ditulis oleh Joseph Atja Sulandra dan Anak Agung Ngurah Roy Sumardika, keduanya mahasiswa Magister Hukum Fakultas Hukum Universitas Udayana, Denpasar, dengan judul “Lembaga Judicial Reviewundang-Undang Terhadap Undang-Undang Dasar : Perbandingan Antara Kewenangan Mahkamah Konstitusi Korea Selatan Dengan Mahkamah Konstitusi Republik Indonesia", yang terbit pada Jurnal Magister Hukum Udayana, Fakultas Hukum Universitas Udayana, Denpasar, Volume 05, Nomor 02, pada bulan Juli Tahun 2016.

Melihat perbandingan jurnal diatas, jelas dapat dikatakan bahwa tidak ada persamaan antara tulisan ilmiah terdahulu dengan apa yang ditulis pada tulisan ilmiah ini. Tulisan ilmiah ini akan memberikan kontribusi baru pada bidang hukum pemerintahan pada bidang Pengaturan Penyelesaian Konflik Norma Antara Peraturan Menteri Terhadap Undang-Undang. 


\subsection{Rumusan Masalah}

1. Bagaimana pengaturan tentang penyelesaian konflik norma antara peraturan menteri terhadap Undang-Undang?

2. Bagaimana sifat putusan mahkamah agung dalam hak uji material?

\subsection{Tujuan Penelitian}

Tujuan umum untuk memahami pengaturan tentang penyelesaian tentang penyelesaian konflik norma antara peraturan menteri terhadap undang-undang.

Tujuan Khusus untuk mengetahui bagaimana pengaturan tentang penyelesaian tentang konflik norma antara peraturan menteri terhadap undang-undang dan unruk mengetahui bagaimana sifat putusan mahkamah agung dalam hak uji material.

\section{Metode Penelitian}

Penulisan ini agar menjadi tulisan ilmiah haruslah dengan menggunakan metode ilmiah pula guna mencari kebenaran yang diinginkan. Metode penelitian yang digunakan yaitu dengan menggunakan metode penelitian hukum normatif, pada prinsipnya metode penelitian normatif yaitu Peraturan digunakan sebagai primer penelitian tersebut atau oleh ahli hukum sering disebut dengan istilah law in books. ${ }^{5}$ Pendekatan yang mendukung guna melakukan penelitian pada tulisan ini mengunakan pendekatan peraturam dan pendekatan konsep hukum. Artinya persoalan pada tulisan ini dianalisis dengan Peraturan perundang-undangan yang menjadi sumber utama kemudian dibantu dengan menggunakan teori, konsep, maupun asas-asas hukum yang relefan dengan permasalahan, sehingga memiliki sumbangsih untuk menyelesaikan permasalahan yang ada. ${ }^{6}$

Sumber hukum yang digunakan yaitu UUD NRI 1945, UU PerundangUndangan, UU MA, dan Permenkumham Nomor 2 Tahun 2019. Sedangkan sumber hukum sekunder yang digunakan yaitu buku-buku atau literatur

${ }^{5}$ Wiguna, I. P. I. P., \& Astariyani, N. L. G. Pengaturan Pengawasan Peraturan Daerah oleh Dewan Perwakilan Daerah Republik Indonesia. Jurnal Magister Hukum Udayana (Udayana Master Law Journal), 8 no. 4 (2019), 539-548. DOI : https://doi.org/10.24843/JMHU.2019.v08.104.p08 · p. 541

6 Setiabudhi, I. K. R., Artha, I. G., \& Putra, I. P. R. A. Urgensi Kewaspadaan Dini dalam Rangka Memperkuat Persatuan dan Kesatuan Bangsa. Jurnal Magister Hukum Udayana (Udayana Master Law Journal), 7 no. 2 (2018)., 250-266. DOI : https://doi.org/10.24843/JMHU.2018.v07.i02.p9 ·p. 251 
terkait dan jurnal ilmiah dibidang hukum, guna menunjang pembahasan pada tulisan ini. ${ }^{7}$

\section{Hasil dan Pembahasan}

\subsection{Pengaturan Tentang Penyelesaian Konflik Norma Antara Peraturan Menteri Terhadap Undang-Undang}

Peraturan Perundang-undangan tidak boleh bertentangan dengan peraturan diatasnya atau peraturan yang lebih tinggi kedudukanya (hierarkinya) ini sudah menjadi prinsip dasar yang dimana terdapat atau tersurat pada Teori Stufenbau. Ini berguna agar tidak adanya tumpang tindih antara peraturan yang satu dengan peraturan yang lain, tumpang tindih norma ini akan menyebabkan suatu ketidakpastian hukum bagi masyarakat. Ketidakpastian hukum ini terjadi karena pada tataran pelaksana maupun pada tataran teknis penegak hukum, akan bingung untuk menerapkan hukum mana atau aturan mana yang harus digunakan untuk menyikapi suatu hal.

Untuk mengkaji suatu aturan mengenai penyelesaian konflik norma antara Peraturan Menteri terhadap Undang-Undang tidak bisa dilihat secara sepenggal-sepenggal, namun harus dilihat secara menyeluruh. Penyelesaian konflik ini mula-mula harus mengetahui siapa yang berwenang untuk melakukan itu semua, tentu saja ini berkaitan dengan kompetensi absolut. Kewenangan untuk menyelesaikan konflik norma antara Peraturan Menteri Terhadap Undang-Undang sebenarnya pada prinsipnya diatur pada UU Peraturan Perundang-Undangan bahwa yang berwenang untuk melakukan pengujian terhadap suatu Peraturan Perundang-undangan di bawah UndangUndang diduga bertentangan dengan Undang-Undang, pengujiannya dilakukan oleh Mahkamah Agung sebagaimana diatur pada Pasal 9 UU tersebut.

Pasal 9 UU Peraturan Perundang-Undangan menyatakan bahwa Mahkamah Agung hanya berwenang menguji apabila Undang-Undang secara norma ditentang oleh peraturan perundang-undangan dibawah UndangUndang. Sedangkan, yang dimaksud dengan Peraturan Perundang-undangan dibawah Undang-Undang yaitu merujuk pada hierarki yang ditentukan pada Pasal 7 dan 8 UU Peraturan Perundang-Undangan. Pada prinsipnya peraturan menteri diakui pada Pasal tersebut dan posisinya adalah dibawah UndangUndang, maka yang memiliki kompetensi untuk menguji peraturan menteri apabila mengalami konflik norma atau konflik peraturan dengan UndangUndang adalah Mahkamah Agung. Mahkamah Agung dalam hal menguji peraturan menteri merupakan kewenangan konstitusionalnya, sebab

7 Tambir, I. M. Pendekatan Restorative Justice dalam Penyelesaian Tindak Pidana di Tingkat Penyidikan. Jurnal Magister Hukum Udayana (Udayana Master Law Journal), 8 no. 4 (2019), 549-574. DOI : https://doi.org/10.24843/JMHU.2019.v08.i04.p09 · p. 555 
kewenangan untuk menguji pada hakekatnya ditentukan pada Pasal 24A UUD NRI 1945 serta itu juga diatur dalam UU MA.

Permasalahan hukum terjadi setelah diundangkanya Permenkumham 2/2019 yang diundangkan tanggal 12 Februari 2019 di Jakarta, yang mengatur yakni peraturan menteri menjadi suatu subjek atau jenis Peraturan Perundangundangan yang diperiksa melalui Mediasi. Permenkumham tersebut bertentangan dengan UU Peraturan Perundang-undangan, karena UU mengatur yang memiliki tugas serta kewenangan untuk melakukan uji peraturan menteri adalah Mahkamah Agung sedangkan permenkumham tersebut peraturan menteri apabila terjadi konflik norma diselesaikan melalui mediasi. Permasalahan hukum antara UU Perundang-Undangan dengan Permenkumham Nomor 2 Tahun 2019 merupakan konflik norma atas bawah atau vertikal, yang artinya memiliki konflik norma secara hierarki atas bawah, ini akan berdampak terhadap kepastian hukum di bidang penyelesaian konflik norma pada peraturan menteri terhadap peraturan dibawah Undang-Undang.

Penyelesaian antara perselisihan norma ini bisa dipecahkan dengan menggunakan asas hukum yang ada dan relevan terhadap permasalahan yang terjadi. Guna menyelesaikan konflik atau perselisihan norma digunakan asas preferensi hukum yang 3 asas yang terdiri atas asas lex superior, asas lex spesialis, dan asas posterior. ${ }^{8}$ i) Asas Lex Superior Derogate Lex Inferior yang memiliki arti aturan yang lebih tinggi mengalahkan aturan yang lebih rendah. ii) Asas lex posteriori derogate lex priori berarti aturan yang lebih baru mengalahkan aturan yang lebih lama yang kemudian dapat dimaknai lebih lanjut bahwa jika peraturan yang berhadapan sederataj maka yang digunakan adalah aturan yang lebih baru daripada aturan yang lama, dapat dilihat dari tahun berapa aturan tersebut di Undangkan. Kemudian asas yang terakhir iii) Asas lex specialis derogate legi generale memiliki makna bahwa aturan yang lebih khusus mengalahkan aturan yang bersifat umum, kondisi ini digunakan apabila aturan dengan derajat atau hierarki yang sama bertentangan norma maka yang digunakan adalah aturan yang lebih khusus daripada yang umum. ${ }^{9}$ Dari ketiga asas preferensi hukum yang ada yang paling cocok dengan permasalahan adalah dengan menyelesaikanya dengan Asas lex superior derogate lex inferior karena asas ini berarti aturan yang lebih tinggi mengalahkan aturan yang lebih rendah, dalam kasus ini yang bertentangan memiliki hierarki atau derajat yang berbeda yaitu Undang- Undang dan Peraturan Menteri.

Sehingga dengan digunakannya asas lex superior derogate lex inferior ini, yang digunakan dengan terjadinya konflik norma antara UU Peraturan Perundang-Undangan dengan Permenkumham Nomor 2 Tahun 2019 terkait pengaturan penyelesaian konflik norma antara peraturan menteri dengan

8 Philipus M. Hadjon dan Tatiek Sri Djatmiati, Argumentasi Hukum, Gajah Mada University Press, Yogyakarta, 2005, p.31

9 Peter Mahmud Marzuki, Penelitian Hukum, Kencana, Jakarta, 2005, p. 101 
Undang-Undang, maka berdasarkan asas tersebut yang digunakan adalah UU Peraturan Perundang-Undangan, sehingga Permenkumham Nomor 2 Tahun 2019 harus dikesampingkan. Maka, Pengaturan mengenai Penyelesaian Konflik Norma Antara Peraturan Menteri Terhadap Undang-Undang, menjadi kewenangan Mahkamah Agung berdasarkan Pasal 9 UU Peraturan PerundangUndangan.

\subsection{Sifat Putusan Mahkamah Agung dalam Hak Uji Materiil}

Judicial Review atau Hak Uji Materiil dimiliki oleh lembaga yudikatif guna melakukan proses pengujian terhadap peraturan perundang-undangan sebagai objeknya untuk menilai apakah aturan itu bertentangan atau tidak terhadap aturan yang lebih tinggi hierarkinya. Hak uji materiil memiliki dua (2) lembaga yaitu i) Mahkamah Konstitusi berwenang melakukan uji materiil produk undang-undang apakah terdapat norma yang bertentangan dengan UUD atau tidak, Sedangkan yang kedua yaitu dimiliki oleh ii) Mahkamah Agung yang berwenang melakukan suatu uji materil kepada peraturan dibawah undang-undangan apakah ada norma yang bertentangan dengan Undang-Undang atau tidak. ${ }^{10}$

Mahkamah Agung untuk melakukan wewenangnya dalam Hak Uji Materiil yang merupakan hak konstitusional Mahkamah Agung yang diatur pada Pasal 24A UUD 1945 pasca amandemen. Diatur juga pada Pasal 9 UU Peraturan Perundang-undangan, dan Pasal 20 UU Kekuasaan Kehakiman. Menurut Paulus Effendi Lotulung, bahwa alasan prosedur Hak Uji Materiil dibuat dalam bentuk produk hukum Peraturan Mahkamah Agung (selanjutnya disebut PERMA). ${ }^{11}$ Kewenangan yang dimiliki Mahkamah Agung dalam melakukan Hak Uji Materiil memiliki makna bahwa Mahkamah Agung berhak dan berwenang untuk menilai materi muatan peraturan perundang-undangan dibawah Undang-Undang terhadap peraturan perundang-undangan yang lebih tinggi dalam hal ini Undang-Undang.

Menurut suripto hak uji materil pada hakikatnya merupakan suatu hak dan kewenangan yang dimiliki oleh badan peradilan yang menjadi lembaga tinggi Negara untuk melakukan pengujian terhadap suatu aturan dengan tujuan guna menilai apakah suatau aturan bertentangan atau tidak kepada aturan yang lebih tinggi. Dalam konteks menguji aturan dibawah UndangUndang terhadap Undang-Undang menjadi tangungjawab Mahkamah Agung. Mahkamah Agung dalam menjalankan tanggungjawab memiliki tujuan agar suatu aturan yang dibuat oleh pemangku kewenangan dapat diuji kelayakannya setelah aturan tersebut disahkan, agar suatu aturan atau produk

10 Andryan, A. Implikasi Putusan Hak Uji Materil di Mahkamah Agung terhadap Legalitas Pimpinan Dewan Perwakilan Daerah Republik Indonesia. Jurnal Penelitian Hukum De Jure, 18 no. 3 (2018)., 367-380. DOI : http://dx.doi.org/10.30641/dejure.2018.V18.367-380 · p. 372

11 Ibid., p. 373 
hukum itu harus tetap berpaku pada aturan, asas serta teori hukum yang ada. Dalam hal adanya suatu permohonan uji materil dengan alas an bertentangan dengan undang-undang, mahkamah agung dalam memberikan putusannya yang pada prinsipnya yang memiliki konsekuensi hukum aturan tersebut apabila terbukti secara sah dan meyakinkan bertentangan dengan aturan di atasnya maka aturan tersebut akan menjadi tidak sah serta tidak berlaku, dan akan menjadi tanggungjawab instansi terkait untuk menarik dan mencabutnya sesuai yang ditentukan oleh Pasal 6 ayat (2) Perma Nomor 1 Tahun 2011. ${ }^{12}$

Kaitannya dengan pengujian formil dan pengujian materil, suatu permohonan uji materil dengan alas an bertentangan dengan undang-undang, mahkamah agung dalam memberikan putusanya yang pada prinsipnya yang memiliki konsekuensi hukum aturan tersebut apabila terbukti secara sah dan meyakinkan bertentangan dengan aturan di atasnya maka aturan tersebut akan menjadi tidak sah serta tidak berlaku, dan akan menjadi tanggungjawab instansi terkait untuk menarik dan mencabutnya sesuai dengan ketentuan. Bukankah istilah "Tidak sah" mengacu kepada makna retroaktif, sedangkan batal mengacu konsep prospektif, atau dengan kata lain jika "tidak sah" berarti dianggap tidak pernah ada peraturan perundang-undangan tersebut. Sehubungan dengan hal tersebut, Bagir Manan menggunakan istilah "batal" dalam konteks putusan yang "prospektif" atau bersifat pro future yaitu putusan yang berlaku ke depan. Dijelaskan: "peraturan perundang-undangan atau perbuatan administrasi Negara dipandang sebagai suatu yang sah sampai saat dinyatakan batal (dibatalkan). Istilah "tidak sah" digunakan dalam konteks putusan "retroaktif" dengan kata lain putusan semacam ini menganggap peraturan perundang-undangan atau perbuatan administrasi tidak pernah ada. Putusan ini bersifat deklaratuir, bukan konstitutif. ${ }^{13}$

\section{Kesimpulan}

Konflik norma antara UU Peraturan Perundang-Undangan dengan Permenkumham Nomor 2 Tahun 2019 terkait pengaturan penyelesaian konflik norma antara peraturan menteri dengan Undang-Undang, maka berdasarkan asas tersebut yang digunakan adalah UU Peraturan Perundang-Undangan, sehingga Permenkumham Nomor 2 Tahun 2019 harus dikesampingkan. Maka, Pengaturan mengenai Penyelesaian Konflik Norma Antara Peraturan Menteri Terhadap Undang-Undang, menjadi kewenangan Mahkamah Agung berdasarkan Pasal 9 UU Peraturan Perundang-Undangan. Dan Sifat Putusan Mahkamah Agung dalam Hak Uji Materiil Mahkamah Agung dalam putusannya menyatakan suatu permohonan uji materil dengan alasan bertentangan dengan undang-undang, mahkamah agung dalam memberikan

\footnotetext{
12 Ibid

13 Simanjuntak, E.. Kewenangan Hak Uji Materil Pada Mahkamah Agung RI. Jurnal Hukum dan Peradilan, 2 no. 3 (2018), 337-356. DOI : http://dx.doi.org/10.25216/JHP.2.3.2013.337-356 · p. 349
} 
putusanya yang pada prinsipnya yang memiliki konsekuensi hukum aturan tersebut apabila terbukti secara sah dan meyakinkan bertentangan dengan aturan di atasnya maka aturan tersebut akan menjadi tidak sah serta tidak berlaku, dan akan menjadi tanggungjawab instansi terkait untuk menarik dan mencabutnya sesuai

\section{Daftar Pustaka}

\section{$\underline{\text { Buku }}$}

Moh. Mahfud M. D. Politik Hukum di Indonesia. PT. Rajagrafindu Persada. Jakarta Utara, (2009).

Peter Mahmud Marzuki, Penelitian Hukum, Kencana, Jakarta, (2005).

Philipus M. Hadjon dan Tatiek Sri Djatmiati, Argumentasi Hukum, Gajah Mada University Press, Yogyakarta, (2005).

\section{Jurnal Ilmiah}

Al Hidayat, N., \& Sari, M. Dualisme Judicial Review Peraturan PerundangUndangan di Indonesia. Jurnal Magister Hukum Udayana (Udayana Master Law Journal), 7 no. 3 (2018), 318-328. DOI : https://doi.org/10.24843/JMHU.2018.v07.i03.p04

Andryan, A. Implikasi Putusan Hak Uji Materil di Mahkamah Agung terhadap Legalitas Pimpinan Dewan Perwakilan Daerah Republik Indonesia. Jurnal Penelitian Hukum De Jure, 18 no. 3 (2018), 367-380. DOI : http://dx.doi.org/10.30641/dejure.2018.V18.367-380

Haryanti, D. Konstruksi Hukum Lembaga Penyelenggara Pemilihan Umum Di Indonesia Ditinjau Dari Teori Stufenbau. Jurnal Pembaharuan Hukum, 2 no. 2 (2015), 270-278. DOI: http:// dx.doi.org/10.26532/jph.v2i2.1437

Setiabudhi, I. K. R., Artha, I. G., \& Putra, I. P. R. A. Urgensi Kewaspadaan Dini dalam Rangka Memperkuat Persatuan dan Kesatuan Bangsa. Jurnal Magister Hukum Udayana (Udayana Master Law Journal), 7 no. 2 (2018)., 250-266. DOI : https://doi.org/10.24843/JMHU.2018.v07.i02.p9

Simanjuntak, E. (2018). Kewenangan Hak Uji Materil Pada Mahkamah Agung RI. Jurnal Hukum dan Peradilan, 2(3), 337-356. DOI : http:/ / dx.doi.org/10.25216/JHP.2.3.2013.337-356

Syamsudin, M. Tinjauan Politik Islam Terhadap Teori Trias Politica. Al Qisthas: Jurnal Hukum dan Politik Ketatanegaraan, 9 no. 1 (2018), 43-61. URL : http://jurnal.uinbanten.ac.id/index.php/alqisthas/article/view/1413/11 $\underline{64}$

Tambir, I. M. Pendekatan Restorative Justice dalam Penyelesaian Tindak Pidana di Tingkat Penyidikan. Jurnal Magister Hukum Udayana (Udayana Master Law Journal), 8 no. 4 (2019), 549-574. DOI : https://doi.org/10.24843/JMHU.2019.v08.i04.p09

Wiguna, I. P. I. P., \& Astariyani, N. L. G. Pengaturan Pengawasan Peraturan Daerah oleh Dewan Perwakilan Daerah Republik Indonesia. Jurnal 
Magister Hukum Udayana (Udayana Master Law Journal), 8 no. 4 (2019), 539-548. DOI : https://doi.org/10.24843/JMHU.2019.v08.i04.p08

\section{Peraturan Perundang-Undangan}

Undang-Undang Dasar Negara Republik Indonesia Tahun 1945

Undang-Undang Republik Indonesia Nomor 12 Tahun 2011 Tentang Pembentukan Peraturan Perundang-undangan (Lembaran Negara Republik Indonesia Tahun 2011 Nomor 82 Dan Tambahan Lembaran Negara Republik Indonesia Nomor 5234)

Peraturan Menteri Hukum Dan Hak Asasi Manusia Republik Indonesia Nomor 2 Tahun 2019 Tentang Penyelesaian Disharmoni Peraturan PerundangUndangan Melalui Mediasi

Undang-Undang Republik Indonesia Nomor 48 Tahun 2009 Tentang Kekuasaan Kehakiman (Lembaran Negara Republik Indonesia Tahun 2009 Nomor 157 Dan Tambahan Lembaran Negara Republik Indonesia Nomor 5076) 